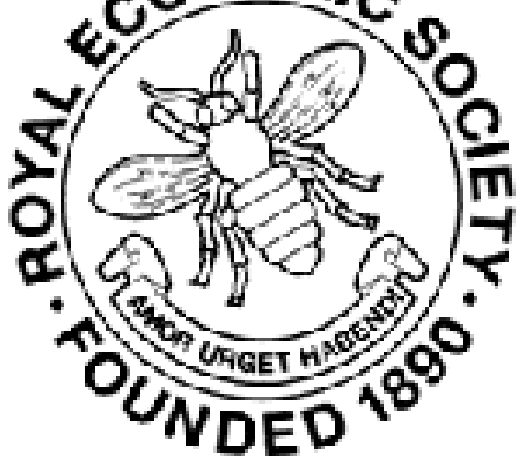

\title{
Review
}

Author(s): Hélène Reinherz

Review by: Hélène Reinherz

Source: The Economic Journal, Vol. 16, No. 61 (Mar., 1906), pp. 107-110

Published by: Wiley on behalf of the Royal Economic Society

Stable URL: http://www.jstor.org/stable/2221149

Accessed: 07-07-2016 15:53 UTC

Your use of the JSTOR archive indicates your acceptance of the Terms \& Conditions of Use, available at

http://about.jstor.org/terms

JSTOR is a not-for-profit service that helps scholars, researchers, and students discover, use, and build upon a wide range of content in a trusted digital archive. We use information technology and tools to increase productivity and facilitate new forms of scholarship. For more information about JSTOR, please contact support@jstor.org.

Royal Economic Society, Wiley are collaborating with JSTOR to digitize, preserve and extend access to The Economic Journal 
first part of the nineteenth century questions which belong only to the last part of it. America did indeed have a labour problem in the eighteenth and early part of the nineteenth century, but it was not the problem we now recognise under that name in America and most other countries, which has only come to be important in America since the great railway strikes of 1877. The early American problem was rather how to organise labour-that is, how to secure a sufficient supply of persons willing to accept the condition of wage-workers for any considerable time. It was not the problem of protecting wage-workers from the oppression of their employers. This earlier problem arose first in the south and was solved there by the establishment of slavery. It was less pressing in the north in early days, but was always felt there. It was encountered in the textile industries, when they first arose, and solved by the employment of women and children in those industries. But it was the immigrant who furnished the ulitmate solution of it for all industries in that section. Early trades unions and labour organisations in America as well as the contemporaneous socialist movements associated with the names of Owen and Fourier in this country, had very little in common with the similar movements in Europe. They were not produced by labour conditions in this country as they were on the other side of the ocean. The prominence given to these subjects by the author rather than any definite expression of opinion concerning them, leads one to infer that she fails to understand their significance, and attributes far greater importance to them in American history than they in fact possess.

Goy Stevens Callender

L'Office du Travail de 1895 a 1905.

A. Lesigne, 1905. Pp. 247.)

By J. Dubors. (Bruxelles :

EvERY institution, in the opinion of the author of this work, owes it to the public to render an account of its achievements at the end of its first decade. The present volume is a history of the origin of the Belgian Labour Department and a description of its aims and activities. It is further intended to serve as a guide to visitors at the Social and Economic section of the International Exhibition of Lièges.

The labours of the Department are partly statistical, partly practical. It set out to inquire into the conditions of labour that exist in Belgium, to study the industrial legislation of other countries, and to draw therefrom inspiration and a moral. The 
personnel of the Department consists of sixty-five officials employed in the central administrative office, twenty-two inspectors, and seventeen labour correspondents who furnish monthly reports. The first task of the Department was to take a trustworthy census, which was published in 1898 in eighteen volumes. This afforded the necessary working data for further investigations. The results of an inquiry into Sunday labour were published in the same year. A report on the rate of wages in mines was published in 1901, and a similar inquiry into the conditions obtaining in the textile industries was begun in the same year. The Department began from its first year of existence, to collect statistics regarding industrial conflicts. 610 strikes, involving altogether 1,519 industrial undertakings, were investigated, and the inquiry points to the conclusion that out of every thousand strikers 101 are successful and 800 see their efforts end in failure -an arithmetical statement which may be a slip on the part of the editor. The proportion of successful strikers varies, we are told, from 1 per cent. in the mining industries to 57 in the chemical and 77 in the printing and bookbinding trades.

In addition to its special inquiries and regular statistical work, the Department has its official organ, the Revue $d u$ Travail, which is published monthly. In point of time this was the fourth journal of the sort to appear, only England and New Zealand having preceded Belgium in this respect. The Revue is purely documentary-it deals in facts, not criticisms, and hence is widely popular.

Industrial Councils were established by law in 1887 to act both as Advisory and as Arbitration Boards. They have often - to quote the words of the editor-put an end to industrial conflicts, and have in any case done much to smooth away difficulties and produce a better understanding between Capital and Labour. Without in any way calling this into question we could have wished for a more definite statement of facts to substantiate it. We get more precise information about the successes of the Conseils des Prud'hommes, representative bodies of employers and employed, which were instituted by Napoleon in 1805. The thirty-three councils actually in existence show a creditable record of 51,000 successfully settled disputes out of 73,000 brought before them between 1890 and 1900.

The Annuaire de Législation is probably the most ambitious undertaking of the Department. It gives the text of the industrial legislation of the year for all countries and their colonies, 
a summary of various decrees and judgments, and in the more important cases a sketch of the inquiry which preceded the legislation. Eight numbers of the Annuaire have now appeared, each, we are told, improving in fulness and accuracy of detail on its predecessor.

The remainder of the book is entirely concerned with the practical activities of the Department. One chapter, copiously illustrated, is devoted to the subject of Inspection, and a sketch is given of the progressive legislation which began with the regulation of the work of women and children in 1889 and culminated in 1903 with the Act which entitles workmen to compensation for accident, even where no case for negligence can be established against the employer. The Government further set itself to encourage Workmen's Insurance Societies by every possible means, granting in the last resort a premium of 60 centimes for every franc invested in the regular accredited societies for Old Age Pensions. Nor did it stop there. Pensions of 65 francs per annum are granted to destitute workmen over sixty-five years of age, at a total cost to the State of thirteen millions annually. This, however, is a temporary measure, which the editor mentions without comment.

The question of Housing was taken up by the Government in 1887, with a special view to encouraging building operations. The workman who wishes to build is accommodated with loan facilities: he can borrow the necessary capital at 4 per cent., plus a contribution to a sinking fund for paying off the debt in fifteen, twenty, or twenty-five years. $\mathrm{He}$ is also required to insure his life in order to cover the debt in case of death before the end of the contract. Within fifteen years about one-tenth of the population has availed itself of these privileges.

Trade Unions were brought within the jurisdiction of the Department by the Law of 1898. At the end of 1903 definite information had been obtained regarding 686 Unions and seven Federations of Unions, but many others prefer to exist unknown to the authorities and free from all risk of interference. The known Unions comprise 7 associations of employers, 42 of artisans, 2 mixed, 606 of peasant farmers, 16 of professional men, 4 of employees, and 9 miscellaneous. The agricultural Unions exist chiefly for the purpose of buying stock and implements on the most favourable terms, the industrial Unions for insurance against slack times. With a few exceptions, the Unions have each their special political bias, i.e. they are Catholics, Liberals, or Socialists. The lines of distinction are 
very sharply drawn-congresses are held of various Unions belonging to the same political persuasion, but no congress has ever yet bridged the gulf between Unions belonging to different political parties.

The volume ends with an imposing list of the laws and decrees affecting industry and the industrial population, which have been passed between 1895 and 1905. The statistical tables throughout the book are good, and the illustrations in the chapter on Inspecting, interesting, though it would be difficult to say on what principle they had been selected. The only complaint we have to make is of a certain lack of clearness in the exposition. In many cases where the history of a movement is traced to its origin the reader is apt to be puzzled as to where exactly the labours of the Department begin. On the whole, however, it is an interesting summary of the activities of the Belgian Government in matters industrial.

\section{HéLÈne Reinherz}

Les Industries à Domicile en Belgique. Vol. VII. Pt. 1 by Ernest Dubois. Pt. II. by Léon Douchamps. (Bruxelles: J. Lebègue et Cie., 1905. Pp. 174, 92.)

Les Salaires dans l'Industrie Gantoise. Vol. II. By Louis VArLez. (Bruxelles: J. Lebègue et Cie., 1904. Pp. cxlv., 239.)

Les Industries Chimiques. (Monographies Industrielles). (Bruxelles: J. Lebègue et Cie., 1905. Pp. 367.)

Annuaire de la Législation du Travail. Se année. 1904. (Bruxelles: J. Lebègue et Cie., 1905. Pp. 595.)

THEse are some of the published reports of the "Office du Travail," of whose work a detailed description has been given above. The first three are special inquiries almost entirely statistical in aim, but a few definite generalisations may be drawn from the mass of detail. We learn that in the linenspinning industry in Ghent, although wages are low-the maximum being 17 francs per week for men and 12.50 francs for women-employment is very regular, and many workers grow grey in the service of the same employer. There is considerable difficulty in obtaining hands-especially women-and a rise of wages is only prevented by a close association of employers. To evade their obligations in this respect individual employers offer gratuities on engagement. The most interesting portion of this 